\title{
CROATIAN CO-OPERATIVES' STORY OF REVIVAL: OVERCOMING INTERNAL OBSTACLES
}

\author{
Jasmina Božić, Armano Srbljinović and Lucija Lučan
}

\author{
Faculty of Humanities and Social Sciences, University of Zagreb \\ Department of Sociology \\ Ivana Lučića 3, 10000 Zagreb \\ e-mail: jbozic@ffzg.hr
}

\begin{abstract}
We conducted semi-structured interviews with leaders or members of 45 Croatian co-operatives covering the different types of co-operatives from all historical regions to identify six main groups of internal obstacles to stronger development of co-operatives in Croatia: 1) those stemming from the "dual" nature of co-operatives, 2) free riding, 3) lack of innovative management, 4) insufficient focus on vertical cooperation among co-operatives, 5) lack of strategic steps toward a division of labor and horizontal cooperation, and 6) underdeveloped cooperation maps and protocols. Upon discussing each of these with a view on how the respective obstacles could be overcome, we conclude that through combined top-down and bottom-up efforts much can still be done to revive hundreds of local co-operatives that have barely survived or are inactive. The co-operatives themselves should be more pro-active in establishing bottom-up platforms for cooperation. Among possible improvements of governmental actions, we particularly recommend extending targeted project grants to also cover specific activities intended to enhance horizontal and vertical cooperation.
\end{abstract}

Keywords: co-operatives, Croatia, horizontal cooperation, networking, qualitative research, small entrepreneurship, vertical cooperation

\section{INTRODUCTION}

Co-operatives are specific forms of associations that combine the features of business enterprises and communities (Draheim, 1955; Rothschild-Whitt, 1979; Puusa et al., 2013). The operation of co-operatives is guided by a set of principles (ICA, 2019), the consequence of which being that members of co-operatives often find themselves in multiple roles - they are investors, patrons, owners, and community members all at the same time (Mazzarol et al., 2011). This, in turn, brings greater freedom, but also greater responsibilities.

Co-operatives have proven to be surprisingly resilient. Since their beginnings in Croatia in the 1860s, they have outlived several very different political and economic regimes, three wars, and numerous economic reforms, some of which have not been favorable to them at all (Mataga, 2009). Worldwide, co-operatives have also weathered the last economic crisis and offered a viable alternative, or at least an interesting complement to the more conventional business world (Stiglitz, 2009; Cheney et al., 2014). 
Yet, unlike in many other countries, co-operatives in Croatia are today mostly struggling to survive. Even though there are 1179 co-operatives in Croatia, far fewer are successful, as only $19 \%$ of co-operatives have been earning about $96 \%$ of the overall co-operative income. Around two thirds (67\%) of co-operatives do not have a single employee, and co-operatives from this category earn $5 \%$ of the overall co-operative income. ${ }^{1}$ What hinders the development of a stronger co-operative sector in Croatia? Are the hindrances surmountable and how can they be overcome? Our qualitative research aimed at answering these questions, among others, and it was undertaken by researchers from the Department of Sociology, Faculty of Humanities and Social Sciences, University of Zagreb, in cooperation with external research associates, along with the assistance of sociology students. Altogether 49 interviews were conducted to include almost all types of co-operatives from all parts of Croatia, and the data thus obtained were thematically analyzed thoroughly with the help of MAXQDA 12 . The project was funded by the University of Zagreb. The main objectives of the project were to obtain a broad overview of the current state of the co-operative sector in Croatia, to identify the main obstacles to the sector's stronger development, and to offer a set of recommendations as to how the identified obstacles could be overcome.

In a related earlier article (Božić et al., 2019), we presented part of our research findings. We discussed the historical backdrop against which the development of the Croatian co-operative sector took place. We also examined in great detail the external obstacles to the development of contemporary co-operatives which comprised inadequate institutional support, insufficient financing mechanisms, and unsatisfactory regulatory framework. Our previous work (Božić et al., 2019) started from the "resource dependence perspective", stressing the context in which organizations - in our case, co-operatives - operate (Pfeffer and Salancik, 1978; Davis and Cobb, 2010), whereas this paper will take the "resource based view" (Barney, 1991), focusing on the internal resources of co-operatives. ${ }^{2}$ The internal resources relate to all intra-co-operative issues, as well as to all inter-co-operative relations, including both those coordinated by co-operative federations (Birchall, 2003; Birchall and Hammond Ketilson, 2009; Novkovic and Golja, 2015) and otherwise. In more general terms, internal problems and obstacles usually play a prominent role in the neo-classical school of economic thought, which commonly holds that market agents themselves are, in the first place, to be praised or blamed for their successes or failures respectively (e.g. Friedman and Friedman, 1980). External obstacles, on the other hand,

1 Whenever data on co-operatives and co-operative unions are cited in this article, the source for this was the web page of the Croatian Center for Co-operative Entrepreneurship, which is no longer accessible. This governmental agency recently lost its independent status and became a unit of the Ministry of Economy, Entrepreneurship and Crafts. We last accessed the web page in mid-2019. We hope that at least some of the data the former Center was collecting, including the Record of Co-operatives and Co-operative Associations, will soon be publicly available again.

2 A detailed account of the differences and similarities between the two views in the context of small business enterprises was provided by Street and Cameron (2007), whereas, as far as we know, Mazzarol et al. (2013) were the first to discuss and apply those views in the context of co-operatives. 
are usually at the center of considerations of institutionalist, as well as developmentalist economics, the former being focused on interactions between economic actors and the institutional surroundings within which they operate (e.g. North, 1990; Edquist and Johnson, 1997; and, particularly in the context of co-operatives, Bijman, 2018), and the latter being focused on the development of productive capabilities of economic actors, which usually also take place against a wider institutional backdrop (e.g. Hirschman, 1958; Amsden, 2007).

Problematizing internal obstacles in this work by no means implies that we subscribe to neo-classical views. However, we do feel obliged to address the issue of internal obstacles, for any account of external obstacles is incomplete without addressing internal ones. Moreover, the two views are very much inter-related, because in order to overcome external obstacles, a co-operative must often have internal strengths, ${ }^{3}$ while overcoming internal weaknesses is usually much easier under favorable external conditions.

Although there is considerable literature about the Croatian co-operative sector (Cvetko, 1908; Puljiz, 1992; Mataga, 1995, 2005; Borbaš and Mikšić, 2003; Petak, 2005; Defilippis, 2005; Matijašević, 2005; Tratnik et al., 2007; Babić and Račić, 2011; Golja and Novkovic, 2014; Novkovic and Golja, 2015; Stanojević, 2015; Pejnović et al., 2016; Vidović and Rakin, 2017; Nedanov and Žutinić, 2018; Đurkin Badurina and Kljaić Šebrek, 2018), some of which are actually comprehensive reviews (Mataga, 2009, 2014; Pavličević, 2010; Broz and Švaljek, 2019), none of these studies, except our previously mentioned one (Božić et al., 2019), included systematic empirical qualitative research based on interviewing the leaders and members of co-operatives.

Studies of co-operative sectors in the countries in Southeast Europe are also mostly reviews (Šoljić et al., 2005; Lambru and Petrescu, 2014; Avsec and Štromajer, 2015; Bojić and Vapa-Tankosić, 2015; Chroneos Krasavac and Petković, 2015). Of the works we were able to identify, perhaps the closest to ours is a study of co-operatives in Serbia (Simmons et al., 2011; Ševarlić et al., 2010), but the two are not directly comparable as the Serbian study was much wider in scope than ours, and it used semi-structured interviews with a range of stakeholders, including those from the government, international and local NGOs, private business federations, academia and co-operatives, as well as a face-to-face survey of co-operative managers.

\section{METHOD}

\subsection{Participants}

We conducted 49 semi-structured interviews with leaders or members of 45 Croatian co-operatives. Among the interviewees were 30 directors, 10 regular members, 1 super-

3 As noted in our previous work, for example, Croatian legislation, particularly the Public Procurement Act, already contains provisions favorable for co-operatives, and the co-operatives themselves need to be more vigilant in using opportunities made possible by those provisions (Božić et al., 2019). 
visory board president, 2 supervisory board members, 2 general assembly presidents, 1 business development manager, 1 project manager, 1 employee who was not a member, and 1 interviewee who identified himself as a "member of management". As most Croatian co-operatives are small, and having contacted the co-operatives via official e-mail, we have good reason to believe that even in the cases of regular members, we interviewed persons who were among the most active in their respective co-operatives. Our sample of 45 co-operatives comprised 23 agricultural co-operatives, 6 social co-operatives, 2 co-operatives that are both agricultural and social, 2 architectural co-operatives, 2 crafts co-operatives, and 1 student, publishing, media, woodworking, techno, housing, finance, energy, fishery and food processing co-operative. Moreover, among those co-operatives, 17 were war veteran in terms of membership. ${ }^{4}$ The co-operatives were included in the sample roughly in proportion to their presence in the population of Croatian co-operatives. We say "roughly" because we were unable to strictly verify proportionality due to problems with non-systematic, partially overlapping and inexhaustive official categorization of Croatian co-operatives, as well as the partially out-of-date Record of Co-operatives and Co-operative Associations maintained by the Croatian Center for Co-operative Entrepreneurship. ${ }^{5}$ Also, while some forms of co-operatives (e.g. finance) represent only a small numerical minority in the population, some of those co-operatives are among the largest in Croatia, justifying their inclusion in the sample.

\subsection{Instruments, data collection and data analytic strategy}

The qualitative research included interviews with questions formulated on the basis of a comprehensive literature review covering various aspects of the functioning of co-operatives such as founding a co-operative, membership, management, employees, co-operative assembly, support from various sources, cooperation, conflict resolution, activities, market successes and failures, regulatory and policy framework, comparison to companies, conditions of co-operatives in Croatia, co-operative alliances, sustainability, and plans for the future. The research was approved by the Department of Sociology Committee on Research Ethics, Faculty of Humanities and Social Sciences, University of Zagreb. Data were collected from September 2017 to March 2018. The conducted interviews lasted for approximately 45 minutes. They were audio recorded, transcribed and any possibly sensitive data were later deleted. Data were analyzed through thematic analysis (Braun and Clarke, 2006; Guest et al., 2011) carried out with the help of MAXQDA 12 software. By reviewing and refining initial coding, the codes were then organized into themes. In this paper we focus on the theme of internal obstacles to the

\footnotetext{
4 War veteran co-operatives in Croatia are often treated as a separate form of co-operative. They are used as a tool for reintegration of war veterans into the workforce. Unlike other co-operatives regulated by the Law on Co-operatives, war veteran co-operatives are regulated by the Law on Croatian Homeland War Defenders and Members of their Families.

5 A detailed account of all these problems can be found in Božić et al. (2019).
} 
development of co-operatives. The analysis and interpretation required insights from a range of related social disciplines and humanities, in particular sociology, law, ethics, economics and history. When analyzing the results, we relied on verbatim quotations from the study participants to illustrate key analytical points (Corden and Sainsbury, 2006; Rose et al., 2015:363-364).

\section{RESULTS}

Several internal obstacles to the successful functioning of Croatian co-operatives emerged from our results, which were then analytically classified into six major categories: 1) obstacles stemming from the "dual" nature of co-operatives, 2) free riding, 3) lack of innovative management, 4) insufficient focus on vertical cooperation among co-operatives, 5) lack of strategic steps toward a division of labor and horizontal cooperation, and 6) underdeveloped cooperation maps and protocols.

\subsection{Obstacles stemming from the "dual" nature of co-operatives}

When examining the internal workings of co-operatives, authors from various disciplines point to their "dual" (Draheim, 1955) nature, meaning that co-operatives are at the same time business enterprises and social groups of members. ${ }^{6}$ Sociologists described the same tension as the one between "formal" and "substantive" rationality (Rothschild-Whitt, 1979). Stated in Weber's (1968) classic terms, co-operatives are supposed to exhibit two types of social action: instrumentally rational and value-rational, the former "aiming at choosing the best means to satisfy a given goal", and the latter aiming "at behaving in a way congruent with principles [the subjects] consider worth following" (Boudon, 2001:42), regardless of any particular goal. It is far from obvious how co-operatives perform a delicate balancing act between the two different requirements stemming from the two fundamentally different principles of social action, so "the viewpoints regarding the significance of the dual nature in practice (...) could be interpreted as somewhat ambiguous or dilemmatic" (Puusa et al., 2013:8).

Indeed, such dilemmatic overtones appear in the words of our study participants, particularly when they need to reconcile the requirements of the real-world business environment with their social concerns:

"... like in any other entrepreneurial undertaking, during the first two, three, up to five years, you have a problem: Do actors recognize you? Once they do, they suddenly start looking for their own interests, that are more of an exploitative kind... the world out there is more the one of market economy, than that of social interest. They do cover themselves up in social interest, yet exploitation and profit are the name of the game. On the other hand, here the

6 Due to their dual nature, co-operatives have been half-jokingly labeled as the "enfants terribles of economics" - too socially focused for mainstream economics, but too economically focused for the non-profit or "third" sector (Levi and Davis, 2008). 
name of the game is our common need, both individual needs as well as common needs. This is not recognized in local and regional governance in our environment, isn't it? Hence we lack support and understanding. The societal aspect should somehow be recreated... " $(9: 65)^{7}$

\subsection{Free riding}

Free riding is one of the central problems in "public goods theories" (Olson, 1965; Hardin, 1968), which examine how to induce collaboration among self-interested individuals, assuming at least some level of collective interest (Flanagin et al., 2001). The problem arises because instead of engaging in costly collective action, it is more rational for the self-interested individuals to simply wait and reap the rewards of others' engagement (Weismuller, 2012). Sociologist James Coleman described free riding succinctly: "If authority has been transferred to a collectivity (...), it will be to the interest of each to let the others do all the work" (Coleman, 1990:78).

In the context of co-operatives and based on our research results, we can illustrate the problem of free riding somewhat informally as: I act through a co-operative when I need the co-operative, while at other times I act in my own private capacity! Indeed, the theme has been recurring time and again in the words of our study participants:

"A co-operative works in the following way: somebody issues a paycheck for a service or a product. The co-operative pays this from those who use that service or product, and retains $5 \%$ of the value of transaction. It seems people have not accepted that a co-operative retains this 5\%. However, a co-operative must have some profit... The book-keeping service costs HRK 1,500 a month, and there are also many other costs. Some people who start working through the co-operative - we do not throw them out - but they simply do not want to sell their goods through the co-operative, except in cases when they have surplus goods that they cannot distribute anywhere, in such cases the price is not an issue..." (22:11)

"... as soon as a member feels sufficiently strong and a customer comes directly to them, the next time the member will not sell via the co-operative any more... It doesn't have to be that way, but we are only human. I can't forbid any member from selling their goods directly to customers... They should do it via the co-operative only, but sometimes they don't. If a customer approaches the member directly, I don't know about that and I can't forbid them. Some members, when approached directly by customers, tell them to go to the co-operative, but some just look how they can get more for themselves only. It's all in human nature!" (38:63) The problem becomes particularly acute when a large company offers better prices: "The co-operative started a project of branding local potatoes. Everything went well until a predatory, large company entered and targeted our members, producers, and they sold their souls for 10 lipas per kilo and switched to the company. They preferred to sell their potatoes to the large company. The co-operative did not get enough potatoes and was not recognized

\footnotetext{
7 Hereafter, whenever a research participant is cited, the first number in parentheses is the participant's ID, and the second number is the beginning line number of the cited excerpt in the MAXQDA project file containing the transcripts of the interviews. Translations from Croatian to English are ours.
} 
on the market. We simply did not have enough quantities to start the brand. So, the project failed because we producers were not united. We had an excellent project, started by our co-operative in cooperation with the Institute of Agriculture, and certified by the Ministry of Agriculture. However, the large company got involved, disunited us, and the project failed." (24:29)

Ironically, the company in question failed in the end as well:

"However, the large company eventually failed, and the co-operative survived, and now the producers are on thin ice. Now well see how they'll behave, for the market they turned to failed." (24:45)

Failing to act with due diligence is a variant of the problem of free riding, as many would like to use some of the co-operative's equipment, but few are willing to care for its maintenance:

"What's not mine, it belongs to nobody... when you offer people the opportunity to use what does not belong to them, to use it as if it is their own property and you charge them a certain amount for the use, not only do they find it hard to pay this amount, but they also do not act with due diligence to maintain the equipment in good condition... this is the first obstacle in people's heads..." (22:44)

Free riding can be overcome when there is mutual agreement and trust that everyone will do their part of the collective task. Unfortunately, that trust is often lacking, as illustrated by a famous example in David Hume's A Treatise of Human Nature (1896:520521), where a farmer considers helping a fellow farmer whose corn had ripened earlier, but eventually abstains, for he does not have guarantees that the fellow would return the favor in due time. Very similar situations, where the lack of trust prevented members of a co-operative from sharing a piece of machinery, or splitting the costs of maintaining it, were described by our study participants:

"Or let's take mowing. Most mowing is done not in April, May, June, September or October, but mostly in July and August, so who'll be the first [to use a tractor]? - I'll be the first! - No, I'll be the first..." (12:38)

"The co-operative applied to a tender of the Ministry of Agriculture in 2009, and it obtained a tractor with a 100 horsepower engine ... I told the co-operative members: if you break any attachments or locks, you need to have it repaired... The tractor cost HRK 320,000, we will use the tractor, but we also need to pay for the repairs. They did not concede to that. One member even asked me whether I would pay rent to the state, as if I got the tractor without a tender. I explained to him what it means to apply to a tender, and asked him why he did not apply, for all were given an opportunity to apply. And so it goes... "(22:37)

In general, the stability of the Croatian third sector is adversely affected by low levels of trust that prevail in all social spheres (Bežovan et al., 2016:44), which is certainly conducive to free riding. Although our study participants did not explicitly address ways of overcoming free riding, the very fact that many co-operatives have existed for years and some are very successful, shows that this obstacle is surmountable. We discuss the issue further in section 4.2 . 


\subsection{Lack of innovative management}

Good management is paramount for successful co-operatives. In principle, co-operatives should "apply the best methods of business administration and management (as far as they can be used to serve the purpose of co-operation)" (Jussila, 2013:3). For small co-operatives, such as the majority of Croatian ones, this is easier said than done. According to our study results, Croatian co-operatives generally seem to be ill-prepared for problem situations that call for some kind of innovative management.

The majority of small co-operatives, particularly those in rural areas and in underdeveloped parts of the country, whenever their work would come to a standstill, whether driven by the fear of losing assets or lacking ideas for alternative routes, would be tiedup and frequently come to a long-lasting impasse. Thus, for instance, a vegetable-producing co-operative disappointed by local tourist accommodation facilities failing to buy up its farm products, would simply cease production for several years, instead of trying to find an alternative, more feasible marketing strategy. There are very many similar examples. However, our aim here is to underscore that even in unfavorable market circumstances there are also positive co-op management practices available related to re-branding, creating new products, using fresh marketing strategies, etc. The following examples illustrate such creative solutions. We hope that they can serve as role models inspiring others to follow in their footsteps.

As to branding strategies, one example is a co-operative that was initially envisioned as a single brand and which remained flexible enough to later evolve into its more appropriate role as a house for several separate recognizable brands of its members:

"Somehow, in the beginning we started with our co-operative as its own brand, but it's now been some two or two and a half years that we realized how an alternative way of doing business suits us better - as a sort of a platform which promotes young designers - because we became recognized mostly for the products of our members, and not so much for the products of the co-operative. So we turned away from the co-operative-as-a-brand approach and concentrated on promoting the products of our designers."

"We are in fact a house for their brands." (29:44)

Another example of a creative solution in the co-operative brand vs. members brand dilemma comes from wine-producing co-operatives which use both alternatives according to the member preferences:

"There are co-operatives on the islands and elsewhere where people simply hand their grapes to a co-operative and expect the value of the grapes to be paid out in return. Because they cannot all have their wineries and so on. Then you also have people who have their products and want to have their own wine brands within a co-operative." (18:6)

A further line of innovative solutions is developed in advance of adverse circumstances. Many agricultural co-operatives purchase products, such as fruits and vegetables from small family farms that are their members, and place them on the market. While some co-operatives leave production planning to the members, others plan their production on the level of the co-operative as a whole (known as "vertically integrated planning"), 
mostly to ensure the continuity of supplies and prevent a lack of supplies in cases when members decide to sell their products to others who offer higher prices: ${ }^{8}$ "Sometimes market demands are higher than supplies and then we have a problem. Co-operants may, of course, go where they can get higher prices and it sometimes happens that we lack supplies for the market. Or, when demand falls, then we have surpluses. We need to somehow regulate both types of situations." (19:27)

Another interesting strategy is visiting fairs with a view to find out what others are doing and what prospective customers need or are looking for. A logical next step is adapting to those needs, which may lead to the creation of new products:

"Visiting fairs and looking at what there is and what customers look for, we were adapting, biennially, with some new products, so that we now produce food for winter storage, sweet and salty: jams, marmalades, juices, pickles, dried meat. Three years ago at a fair we were awarded First Prize for our innovation - smoked and brined freshwater fish in jars... Fishermen did not catch that type of fish and even when they would accidentally catch it, they would throw it back into the river as it did not have value for them. But we were successful in increasing its commercial value, and started buying this fish from the fishermen and launched a new quality product." (11:18)

An innovative marketing idea was conceived by a co-operative from the continental region of Slavonia, which received support from local self-government units to promote and sell its products in tourist centers on the Adriatic Coast:

"At the very beginning, we sent a written notice to all the local self-government units, from municipalities and cities to tourist boards, so that they know we exist. We sent a product specification sheet and photos on a CD to their addresses, sending over 200 such packages all throughout Croatia. Okay, some did not respond, but some sent us invitations, within a month, to install sales stands in, for instance, Dubrovnik, Cavtat, Split, Baška Voda, Trogir, etc. We had to cover travel expenses, but all other expenses were covered by the local self-government - this means that we did not have to pay for the stands to exhibit these Slavonian delicacies." (11:54)

Most of the examples in this section were relatively simple cases of productive "thinking outside the box". Yet, in the example of the freshwater fish, open-mindedness eventually led to a genuine innovation in the form of a new product. Ideally, we would like to have more examples of such innovative and less deadlocked or defunct co-operatives. We will return to the issue of obstacles to innovation in section 4.3.

8 However, vertical integration also has its downsides. Albæk and Schultz (1998) argue convincingly that it is precisely decentralized planning that allows co-operatives to outperform vertically integrated firms because a decentralized co-operative produces more than a vertically integrated firm, although at a lower price. This is possible because although an individual member may realize that an increase in production will decrease the price in the final market, they only internalize (i.e. take into account in their calculations) their own part of the profit loss stemming from the price decrease, and not also the profit losses that the other members may suffer from the price decrease. So, vertically integrated planning may be preferable when continuity of supplies is paramount, as in our example above, but in good years decentralized planning may be more desirable. 


\subsection{Insufficient focus on vertical cooperation among co-operatives}

Elsewhere we discussed the manifold benefits of the integration of co-operatives into larger co-operative units, such as co-operatives of co-operatives, regional or other kinds of co-op federations, etc., which is known as "vertical", in contrast to "horizontal", cooperation among co-operatives, such as cooperation in the supply chain, mergers and consortia-type arrangements (Božić et al., 2019; Vallati, 2012). The issues of policy influence, advocacy, co-operative sector development, and connections to the international co-operative movement are particularly known to be best dealt with by co-operative federations (Birchall, 2003; Birchall and Hammond Ketilson, 2009; Novkovic and Golja, 2015). While in neighboring Slovenia there is a plethora of vertical (and also horizontal) cooperation examples (Avsec and Štromajer, 2015), in Croatia there are but a few. Some of the reasons for this state of affairs lie not with the regulatory frame or lack of government-led systematic efforts on integration, but with the co-operatives themselves (Cogeca, 2010; Novkovic and Golja, 2015). For instance, co-operatives dealing with particular issues, such as publishing or architecture, are few, geographically dispersed across the country and usually working on very specific, narrowly defined issues. A small number of specialized co-operatives and their geographical dispersion are structural problems that cannot be easily dealt with, but sometimes these co-operatives also seem to be unusually unwilling to break out of their comfort zones:

Q: "Do you co-operate with some other co-operatives with similar activities?"

A: "Unfortunately, no. There is only one such co-operative as far as I know in Zagreb, but maybe there are more co-operatives working in the area of culture in some other Croatian regions. There were several new initiatives that I saw in this area in the last ten years and I even tried to establish private connections with them, but they... were specialized for some aspects of work that are not really complementary with the exotic topics of my co-operative, and literary and scientific publications that we published." (30:93)

The few existing co-operative federations, i.e. regional and branch co-operative associations, in Croatia are rather weak and insufficiently active:

"There is, I think, a Croatian Association of Co-operatives. Practically each co-operative must be a member of that association. There are also regional associations, such as the Regional Association of Co-operatives in Istria. However, as co-operatives have not developed well in Croatia, it's just as well that these associations do not work... I don't remember when the latest assembly of either the Croatian Association of Co-operatives or the Regional Association of Co-operatives in Istria was held. So, we don't have support from that side either. When co-operative associations do not work, then what more is there to say?" (24:39)

However, there are also praiseworthy activities of regional associations, such as the traditional International Meeting of Winemakers and Winegrowers "Sabatina" and the International Olive Oil Exhibition "Noćnjak", both organized by the Co-operative Alliance of Dalmatia.

The only supportive institution at the national level that our study participants tended to view more positively as being more responsive to the immediate needs of co-operatives is the Ministry of Croatian Veterans, which was supportive of course only toward 
war veteran co-operatives. There are some indications that membership in certain international co-op federations could be useful, but, as we already mentioned, such links are most easily established by federations, and they are currently too weak to be effective in that regard. Consequently, the burden of international cooperation again largely rests on the shoulders of the individual co-operatives themselves:

"Furthermore, we have been a member of the European Federation of Renewable Energy Co-operatives for three years already, and this year we were elected as one of its Board members. It is an organization with, I think, over 1,500 co-operatives which are full members of the Federation, but it also represents a much larger number of around a million citizens of the EU in total." (41:30)

\subsection{Lack of strategic steps toward a division of labor and horizontal cooperation}

Another type of internal obstacle is rooted in the lack of a strategic vision for the development of co-operatives on the principles of division of labor and horizontal cooperation, both within and among co-operatives. Firstly, by way of thoughtful analysis it is possible to achieve a division of labor within a co-operative, among members, along the lines of professions needed for a co-operative to thrive. In our research we came across a number of small local co-operatives consisting of members associated by kinship or friendship, yet lacking members with particular skills or those who could cover a particular production phase. This proved to be one of the reasons for a business standstill. As illustrated by the following participant's words, it is possible in such circumstances to invite into membership people of professions or skills that differ from those that existing members already have:

"I am a computer engineer, and I would very much like to find someone who would be interested in that kind of job within the co-operative. Then we could make a very large piece of the pie ourselves. And I also have a couple of projects where we could even expand our business. On the other hand, I also need someone who would be willing to deal with transport... It is a large burden for me to allocate HRK 150,000-200,000 for a van, plus a driver, whereas someone could secure a job in that way. There are a whole bunch of things where one could go in. I would also free myself of some book-keeping overhead... These are simple problems to solve, when there is a will, when there is a will." (12:72)

Another aspect of such strategic vision would lead toward the horizontal cooperation of co-operatives dealing with different but complementary production and product dissemination phases. Thus, for instance, an illustrative example comes from a co-operative planning ahead to establish cooperation with a co-operative dealing with packaging and another one dealing with transport:

"So the goal is to cover all the expenses. Of course, in addition to that goal, which every economic agent probably has, we would like to increase the number of co-operants, connect with other co-operatives from the region and in a similar field of activity, as well as with a co-operative dealing with packaging and another one dealing with transport. Because when we could manage to do that, then all of us could cut some of our expenses." (19:27) 
This may be accomplished either within a single county, where, through a strategic vision by co-operative federations or by local government developmental agencies, it is possible to induce co-operatives to cover particular production phases, such as growing fruit, packaging, transport and delivery, sales, etc. It is not realistic to expect that any co-operative would come up with such a vision on its own and implement it, as the implementation of such a vision would sometimes require that new related co-operatives with the aim of specialization be established. In the next example we see planning of such caliber by a manager of a strong local co-operative.

"I was first a director and founder of a co-operative with the purpose to engage retired persons who were still able to work, as well as persons with disabilities. However, in time, this developed into a very powerful co-operative with a whole range of operations. And then the need for more specialized co-operatives appeared, and we established three more co-operatives: one which would deal with administration, legal issues, services - to be the 'brain', so to say; one to be oriented toward development, trying to deal with various things, the selection of which would show which could be retained; and the third to deal with fyer distribution." (9:3)

Unfortunately, these plans remained largely unimplemented.

Furthermore, through regional planning, market research and some necessary investments, it is possible to establish co-operatives of different but complementary specialization in different parts of the country. The following participant undertook such an endeavor - unfortunately without any success, due to a complex set of political and other obstacles.

"When we started to do analyses, we found that our raw-materials base in Zagorje was too small, so we expanded to Slavonia, established six agricultural co-operatives there, found a man who would lead the endeavor - a German who was delighted in realizing similarities with Raiffeisen-type of co-operatives. We also formed some seven or eight co-operatives on the Adriatic coast, and also had our man there... Why? Slavonia would produce, and we would here process some 1000 pieces, but it's still too little."(13:41)

\subsection{Underdeveloped cooperation maps and protocols}

Our findings have revealed that the majority of Croatian co-operatives have made attempts towards establishing cooperation with other co-operatives, companies, family farms, associations, municipalities, municipal offices for economy, municipal offices for disability and social protection, community colleges, employment agencies, Local Action Groups (LAG), etc. Albeit these attempts have been limited, sometimes they are successful. Cooperation is being established for various purposes. Co-operatives work together for the purpose of helping and counseling each other, joining forces in order to produce enough to be able to cooperate with Podravka, Lidl and other large companies seeking guarantees that a certain quantity of products will be delivered in a certain time period, etc. Co-operatives work with family farms in a variety of ways, for instance by supplying them with fertilizers, protective equipment or even land, buying up of farm products and producing ready-to-use products. Co-operatives work with companies 
sometimes by selling their products. Co-operatives frequently work with associations, municipal offices for disability and social protection, community colleges and employment agencies on developing social entrepreneurship projects employing persons with disabilities. Co-operatives also work with municipalities by inviting them to invest into co-op business and also become members of a co-operative or of the supervisory board of the co-operative they invested into. As parts of LAGs, co-operatives contribute to balanced and sustainable local community development.

Cooperation has taken a multitude of forms, including outsourcing, forming co-op sections, start-ups, connecting internal and external resources in miscellaneous ways. Moreover, very rarely did participants indicate that there were any problems in cooperation with partners:

"We have multiple examples of successful cooperation with several civil associations, Public Open University, Employment Service, City Offices for people with disabilities, social protection, economy. We also have good cooperation with the economic sector. And the Association of the Blind - I cannot emphasize this enough! Last year we completed a project where five blind or visually impaired persons were employed and they now produce soaps with dots. These are corporate gifts and we are very proud of that project. This is an example of good practice, isn't it? Two years ago, we didn't even know each other, and now they have their own production, they even prepare to enter cosmetics production, and they have their own enterprise and develop social entrepreneurship through that enterprise." (33:29)

The problems they indicated were mostly typical of any business enterprise, e.g. they stemmed from low prices, insolvency of partners or not paying sufficiently for jobs done, free riding, or simply people who did not live up to the expectations. Most frequently participants claimed that their co-operative was willing to adapt to partners.

However, our analysis also indicates that possibilities of cooperation remain largely underexplored among the majority of co-operatives. While the overall insight into the state of play presented manifold opportunities for cooperation, it seems that only a few co-operatives have been fully aware of them. Most co-operatives have tried only a mere segment of the available opportunities, unaware of the vast horizon it offers. When cooperation with other subjects is established, it is more often a result of serendipitous circumstances rather than concerted action.

Therefore, we have come to the conclusion that cooperation practices have not been turned into cooperation protocols and presented to co-operatives at large through education workshops. This task should have been carried out long ago by the former national Croatian Center for Co-operative Entrepreneurship, regional co-op federations or regional development agencies. True, there have been various education workshops for co-operative members and leaders, but most of them remained at the level of the unsystematic presentation of good practice examples, rather than being aimed at establishing lasting cooperation arrangements. For this purpose, analytical efforts should be strengthened with the aim of not only collecting examples of good practice among successful co-operatives, but also generating both maps of possible types of partners, who could form sound networks, and cooperation or networking protocols that would 
lead co-operatives in their networking steps. Currently, due to the lack of cooperation maps and protocols, there is not enough replication of good practice examples which often remain isolated one-shot efforts instead of being widely diffused and reproduced.

\section{DISCUSSION}

In this section we discuss each of the groups of obstacles identified in the preceding section trying to indicate possible ways of overcoming them.

\subsection{Obstacles stemming from the "dual" nature of co-operatives}

As we already noted, the "dual" nature of co-operatives features prominently in various discussions on co-operatives. Most often, discussions about co-operatives and their prospects for success emphasize either the instrumentally-rational (Bonin et al., 1993; Hansmann, 1996; Albæk and Schultz, 1998; Ménard, 2004) or the value-rational (Rothschild-Whitt, 1979; Borgström, 2013) aspects of co-operatives as being crucial. We can therefore ask: which of the two "Janus faces" (Zamagni and Zamagni, 2010) do Croatian co-operative members turn when they are reporting about their achievements? Although co-operatives that survive in an inhospitable environment must be efficient - after all, the sheer fact of their viability is proof of their efficiency - a majority of the research participants, particularly those from the more successful co-operatives, emphasized the value-rational aspects of their activities, especially commitment to co-operative principles, co-operative spirit and solidarity, perseverance in the face of adversity and the like. When instrumentally-rational aspects appeared in their words, they were most often related to long-term goals, such as viability and sustainability, indicating that most of the Croatian co-operative members are "long riders", happy to do what they feel is "the right thing", and regarding profits as beneficial side-effects rather than goals in their own right:

"I bring profit, I pay VAT, thus I pay everything, trust me, I give enormous sums of money to this state and to the local self-government. I save people. When I see people searching for empty bottles in garbage containers, I want to cry. These are old people. When I manage to employ a retired person, I'm the happiest person on Earth!" (8:73)

"Economic cost effectiveness means sustainability to us. Our focus is not on profit, that is the first pillar. The second pillar is social utility which is measured by how many people in unfavorable positions do we include into our activities, educate, prepare for employment and self-employment. The third pillar is ecology - what materials do we use and reuse, what do we use for heating, driving, etc." (33:18)

Thereby the key to dilemma resolution among our study participants is to affirm understanding that value rationality will pay off in due time in a long-term perspective, as it happened in the case of Humana Nova, one of the major social co-operatives in Croatia (Posavec, 2018). 


\subsection{Free riding}

In the tradition of rational choice theory, the problem of free riding is most often dealt with by monitoring and sanctioning of free riders. However, monitoring and sanctioning often require costly collective action and again lead to free riding (Hechter and Opp, 2001). Thus the question of who will monitor and sanction "free riders of higher orders", i.e. those who do not monitor and sanction "free riders of lower orders", recurs again and again and ultimately leads to infinite regress (Barclay and Kiyonari, 2014). Apart from such feasibility problems, policing is also largely incompatible with the spirit of cooperativeness itself, particularly with its principles of voluntary and open membership, and democratic member control (ICA, 2019; Novkovic, 2008; Jussila, 2013).

The main alternative to external monitoring and sanctioning is internalization of co-operative norms. Note that the latter is equivalent to internal monitoring and sanctioning, for potential transgressors themselves are to feel distress, guilt, compunction and other negative emotions which can be regarded as the "psychic costs" of their transgressions (Turner and Stets, 2005). Various factors such as trust, reciprocity, social rewards (e.g. reputation, popularity, prestige; Hechter and Opp, 2001), and sense of ownership (Borgström, 2013) have been suggested to facilitate the internalization of co-operative norms.

Research on the impact of those factors on the internalization of co-operative norms within and among co-operatives is still in the early phases. As an example, a study of co-operatives in Northern Minnesota found a direct connection between reciprocity and interorganizational commitment to cooperation and revealed interpersonal commitment to cooperation as a mediator of the relationship between trust and interorganizational commitment to cooperation (Pesämaa et al., 2013). Another study of co-operatives on the Iberian Peninsula found that the corporate reputation of a co-operative had significant effects on the loyalty of the co-operative's members and on the co-operative's performance (Casimiro Almeida and Coelho, 2016). As to the sense of ownership, it has been suggested that both economic incentives and organizational culture - in particular autonomy, influence in company-wide issues and, to some extent, participation in local decisions - impact on its intensity (Ownership Associates, 1998, 2001). This is why the earlier mentioned dual nature of co-operatives, as business and social enterprises, makes them particularly suited for putting into place both economic incentives and organizational culture conducive to the development of an intense sense of ownership (Mazzarol et al., 2011). While most such findings are somewhat inconclusive, they indicate the importance of trust, reciprocity, social rewards, and sense of ownership as facilitators of cooperation and safeguards against free riding within the co-operative's organizational settings. Note also that the examples above feature both individual-level (reciprocity, trust, interpersonal commitment, loyalty) and organization-level constructs (interorganizational commitment, corporate reputation, co-operative's performance), as the two levels are inter-related.

In the long run, inter-generational transmission of co-operative norms is important for the internalization of co-operative norms among youth. Although our research did not 
cover these, pupils' co-operatives may be particularly valuable in this regard (Vidović and Grubišić-Čabo, 2019).

\subsection{Lack of innovative management}

The ill-preparedness of mostly small Croatian co-operatives for problem situations that require innovative management may be, according to our study participants, related to a lack of adequate materials and human resources:

“... another problem stems from inadequately developed internal capacities such as technical and financial, as well as quality and educated human resources. The co-operative $X$, just like most entrepreneurs in the valley of the river $Y$, lacks the necessary capacities and it is not able to follow challenges in the field of food production and security in line with the more and more demanding domestic as well as foreign market." (26:22).

Brat et al. (2016) identified time pressures, inadequate selection of the right ideas, and risk-averse culture as three major obstacles to innovation in co-operatives. The same authors also pointed to development, prioritizing and funding the right ideas as the key challenges in driving innovation in co-operatives (Brat et al., 2016). Further research is needed to see which of these obstacles and challenges are most pertinent to Croatian co-operatives. For now, based on the examples given in section 3.3, we can guess that small co-operatives with scarce resources most likely have problems with generating and selecting the right ideas.

As for the risk-averse culture, this has been generally associated with co-operatives as they are "usually focused on proximity and service to members, but not necessarily on innovation and risk-taking" (Brat et al., 2016:13). ${ }^{9}$ We can also add that in the last ten years Croatia has usually ranked between 40th and 50th place among 129 countries, according to Global Innovation Index reports from 2011 to 2019 (available at GII, 2019). It is striking to note that one of Croatia's lowest scores is in University / Industry Research Collaboration (Dutta et al., 2019), which fits well with our previous recommendation to enhance cooperation between the Croatian co-operative sector and academic institutions (Božić et al., 2019).

\subsection{Insufficient focus on vertical cooperation among co-operatives}

Novkovic and Golja (2015) listed three main obstacles to the emergence of stronger co-operative federations in Croatia: (1) wide gap between traditional and newly emerging co-operatives, (2) lack of foreign investments, and (3) insufficient networking between co-operatives tied to social movements and more traditional co-operatives. While we were not able to identify these from the collected interviews, it may very well be that they are also blocking progress toward stronger vertical integration within the sector.

9 This seems to be less problematic for larger co-operatives, such as Mondragon, which adopted "constant renewal" as one of the corporate values at the heart of its organizational culture (Agirre et al., 2009). 
Let us note that free riding is also possible at the level of co-operatives as organizations since cooperation among co-operatives can be regarded as costly collective action. For example, formative investments into interorganizational linkages such as federations of co-operatives may be insufficient or absent due to the expectations of most co-operatives that some other entity would be the first to start the endeavor. However, Flanagin et al. (2006) showed that this kind of free riding can be overcome by having incentives to occupy a central position in the emerging interorganizational network and to wield influence over everyday operations of organizations within the federation.

Indeed, one of the largest co-operatives in Croatia, Co-operative for Ethical Financing (ZEF), which has been particularly active in establishing interorganizational linkages and has already succeeded in attracting 19 co-operatives within its membership (Bekić, 2019), now enjoys a central position and considerable influence in the sector. In part, this was possible because ZEF has been able to garner expert knowledge in various areas pertinent to co-operative enterprise, such as drafting legal documents, business plans and grant applications, business management, and book-keeping services. This example is also instructive regarding the importance of diligent application of co-operative principles, in this case Principle 5 - Education, Training and Information, and Principle 6 - Cooperation among Co-operatives (ICA, 2019), as well as of the powerful synergies arising when the principles are applied in conjunction.

Generally, we see the bottom-up ${ }^{10}$ establishment of such platforms for integration of the sector as the right way toward stronger vertical cooperation, particularly if backed by adequate governmental regulations facilitating branch associations and other types of vertical integration such as co-operatives of co-operatives, as well as with regional and local self-government units facilitating regional associations, in line with the specific needs of co-operatives within their branches, and regions, respectively (Božić et al., 2019).

\subsection{Lack of strategic steps toward a division of labor and horizontal cooperation}

Although, as we already noted, the primary roles of co-op federations are in using vertical integration for policy influence and advocacy, in line with the "stronger together" principle, there is also room for federations to help horizontal cooperation among co-operatives. In addition to promoting good practice examples, such as those mentioned in section 3.5, federations could also set aside some buffer funds from their members for cases of failed investments through horizontal partnerships, or to finance the recovery of co-operative enterprises stricken by natural disasters, such as draughts, fires or floods. Federations could be more pro-active in building trust needed for horizontal cooperation among their members, as well as in conferring reputation by annually awarding meritorious members or "the best co-operators". Finally, co-op federations could also be more pro-active in assembling consortia that would apply for EU or other project funds.

10 By "bottom-up" efforts we mean those efforts initiated by co-operatives and their members, whereas by "top-down" efforts we mean efforts initiated by the government and / or its agencies.

11 Yet, "regeneration" of "degenerated" co-operatives is also possible (Storey et al., 2014). 
When discussing both the horizontal and vertical integration of co-operatives, we have to keep in mind that the growth of co-operatives may also induce the erosion of participatory practices, with either failure or alignment to conventional corporate structures as a consequence (Sivertsen, 1996; Rybnikova and Hartz, 2014). In particular, there is a danger of demutualization - the turning of co-operatives into for-profit, proprietary organizations (Mathews, 2003; Galor, 2008) ${ }^{11}$ However, as most Croatian co-operatives and co-op federations are currently very small, we see the benefits of horizontal and vertical integration as vastly outweighing the risks of demutualization at this stage of the development of the Croatian co-operative sector.

\subsection{Underdeveloped cooperation maps and protocols}

There is an important role of applicative research in collecting good practice examples of cooperation and networking, but also analytically crystallizing and clarifying core procedures, presenting possible pathways of connections, and thus generating an overall picture that single co-operatives, often being rather small and scattered throughout the country, are unable to see by themselves. Ideally, this should be done by the combined efforts of national and regional bodies top-down and co-op federations bottom-up.

The establishment of cooperation maps and protocols should proceed in such a way that these activities do not further increase the already considerable paperwork burden on co-operatives. ${ }^{12}$ The maps and protocols should not be overly imposing, yet they should clearly identify all the stakeholders with whom cooperation could be established, as well as possible types of cooperation with each of the prospective partners. Additionally, fairs and exhibitions could feature dedicated brokerage events, where representatives of co-operatives and other interested partners could present their cooperation offers / requests and engage in other matchmaking activities. Co-op federations should also be more pro-active as platforms where co-operatives could discuss common issues, develop interconnections and obtain information about possible partners.

When discussing innovation, we have already pointed to the need to enhance cooperation between the Croatian co-operative sector and academic institutions. There is also ample room for such cooperation in the aforementioned applicative research eventually leading to the development of appropriate cooperation maps and protocols. The lack of such an integrative vision that should have been developed long ago has contributed to the current plight of Croatian co-operatives.

\section{CONCLUSION}

We identified six main groups of internal obstacles to the stronger development of Croatian co-operatives: 1) obstacles stemming from the "dual" nature of co-operatives, 2) free riding, 3) lack of innovative management, 4) insufficient focus on vertical coopera-

12 As one of our study participants put it: "We produce papers, instead of food" (6:22). 
tion among co-operatives, 5) lack of strategic steps toward a division of labor and horizontal cooperation, and 6) underdeveloped cooperation maps and protocols. We also discussed possible ways of overcoming these obstacles in terms of both how our study participants saw them, and what the relevant academic sources have to say about them. When we turn to practice, the natural source to look to for help in overcoming the obstacles are the co-operative principles (ICA, 2019; Novkovic, 2008), and among these we see cooperation among co-operatives as the key to development of stronger and more sustainable national and international co-operative sectors. The principle suggests that "by working together (through local, national, regional, and international structures) co-operatives can extend their members' freedom to command all kinds of operations instead of remaining subservient to them" (Jussila, 2013:2).

Indeed, stronger horizontal and vertical cooperation among Croatian co-operatives could increase their capacities by pooling and sharing practices, strengthen their supply chains, increase their policy influence as well as the ability to promote their common cause. Moreover, intensification of cooperation would contribute to the development of trust and reciprocal relations among co-operatives, bestow reputation to "the best co-operators" and facilitate internalization of co-operative norms among members. In other words, the best way to curb free riding is to show that other ways of behavior are not only possible, but also viable in practice. Enhanced communication among co-operatives would also enable diffusion of best practice examples, including innovative management solutions to recurring common problems.

Co-operatives themselves should be more pro-active in establishing bottom-up platforms for cooperation, as in the case of the Co-operative for Ethical Financing. Although bottom-up initiatives are crucial, their chances to success are slimmer without adequate top-down involvement. Elsewhere we recommended what state administration, governmental agencies, and local and regional self-government units could do in terms of better legislation and enhanced institutional support (Božić et al., 2019). We also noted that project grants for targeted co-operative activities seem to be more beneficial than direct subsidies (Božić et al., 2019). ${ }^{13}$ In light of the findings of this article, we can recommend extending such grants to also cover specific activities intended to enhance cooperation among co-operatives, such as the organization of brokerage events and joint research projects involving partners from both the academic community and co-operative sector. The joint research projects should give priority to further research on ways of reconciling the instrumental vs. value rationality dilemma, factors facilitating internalization of co-operative norms, intensification of innovation practices in co-operatives, networking and forming strategic alliances among co-operatives, as well as development and codification of cooperation maps and protocols.

13 An example is the annual call "Development of Co-operative Entrepreneurship" (Ministry of Economy, Entrepreneurship and Crafts, 2019). 


\section{Funding}

This work was supported by the University of Zagreb allotting a grant through the Faculty of Humanities and Social Sciences to the project "Success Factors and Cooperation Models of Co-operatives in Croatia", which covered the expenses of the preparatory phases, data gathering, analysis and interpretation.

\section{Acknowledgments}

This paper is a thoroughly extended and revised version of the presentation given at the $7^{\text {th }}$ National Congress of the Croatian Sociological Association, Zagreb, Croatia, 11-12 April 2019. The authors would like to acknowledge the invaluable assistance in collecting data by professors Davorka Matić and Anton Vukelić from the Department of Sociology, Faculty of Humanities and Social Sciences, University of Zagreb; Iva Marija Ilić, M.A., from the National Foundation for Civil Society Development; Karlo Karija, and other students of sociology at the mentioned Department. We also wish to thank two anonymous reviewers for their helpful comments and insights. 


\section{REFERENCES}

Agirre, A., Lizarralde, I., Altuna Erle, R., and Grellier, H. (2009). Building up an innovation region through cooperative experiences. Pôle Sud, 2(31): 71-86.

Albæk, S. and Schultz, C. (1998). On the relative advantage of cooperatives. Economics Letters, 59(3): 397-401.

Amsden, A. (2007). Escape from empire: The developing world's journey through heaven and hell. Cambridge, MA: The MIT Press.

Avsec, F. and Štromajer, J. (2015). Development and socioeconomic environment of co-operatives in Slovenia. Journal of Co-operative Organization and Management, 3(1): 40-48.

Babić, Z. and Račić, D. (2011). Co-operatives and social economy in Croatia: Trends, indicators and prospects in the European context. Sociologija i prostor, 49(3): 287311. [Full text in Croatian only]

Barclay, P. and Kiyonari, T. (2014). Why sanction? Functional causes of punishment and reward. In: Van Lange, P. A. M., Rockenbach, B., and Yamagishi, T. (eds.), Social dilemmas: New perspectives on reward and punishment (pp. 182-196). Oxford: Oxford University Press.

Barney, J. B. (1991). Firm resources and sustained competitive advantage. Journal of Management, 17(1): 99-120.

Bekić, A. (2019). Personal communication with authors via LinkedIn, 12 September 2019.

Bežovan, G., Matančević, J., and Baturina, D. (2016). Identifying external and internal barriers to third sector development in Croatia. Third Sector Impact National Report Series, No. 5. Brussels: European Union.

Bijman, J. (2018). Exploring the sustainability of the cooperative model in dairy: The case of the Netherlands. Sustainability, 10(7). DOI: 10.3390/su10072498.

Birchall, J. (2003). Rediscovering the cooperative advantage: Poverty reduction through self-help. Geneva: International Labour Organization. URL: http://base.socioeco. org/docs/jb1.pdf (11.09.2019.)

Birchall, J. and Hammond Ketilson, L. (2009). Resilience of the cooperative business model in times of crisis. Geneva: International Labour Organization. URL: https:// www.ilo.org/wcmsp5/groups/public/---ed_emp/---emp_ent/documents/publication/wcms_108416.pdf (11.09.2019.)

Bojić, B. and Vapa-Tankosić, J. (2015). Legal status, role and importance of agricultural cooperatives in Serbia and in the European Union. Kultura polisa, 12(27): 395-410.

Bonin, J. P., Jones, D. C., and Putterman, L. (1993). Theoretical and empirical studies of producer cooperatives: Will ever the twain meet? Journal of Economic Literature, 31(3): 1290-1320.

Borbaš, T. and Mikšić, M. (2003). Poljoprivredne marketinške zadruge. Zagreb: Hrvatski zavod za poljoprivrednu savjetodavnu službu.

Borgström, M. (2013). Effective co-operative governance: A practitioner's perspective. Journal of Co-operative Organization and Management, 1(1): 49-50. 
Boudon, R. (2001). The origin of values: Sociology and philosophy of beliefs. New Brunswick: Transaction Publishers.

Božić, J., Šprajc, I., and Srbljinović, A. (2019). Croatian co-operatives' story of revival: Overcoming external obstacles. Journal of Co-operative Organization and Management, 7(2). DOI: 10.1016/j.jcom.2019.100090.

Brat, E., Buendia Martínez, I., and Ouchene, N. (2016). Innovation: Priorities and practices in cooperatives. Montréal: Alphonse and Dorimène Desjardins International Institute for Cooperatives. URL: http://institutcoop.hec.ca/wp-content/ uploads/2016/10/Innovation-priorities-practices-cooperatives-2016-EN-web.pdf (06.12.2019.)

Braun, V. and Clarke, V. (2006). Using thematic analysis in psychology. Qualitative Research in Psychology, 3(2): 77-101.

Broz, T. and Švaljek, S. (2019). Mikrokozmos zadružnog gospodarstva: gdje i kako posluju hrvatske zadruge? Sociologija i prostor, 57(2): 107-138.

Casimiro Almeida, M. G. and Coelho, A. (2016). The role of corporate reputation on co-operants behavior and organizational performance. Journal of Management Development, 35(1): 17-37.

Cheney, G., Santa Cruz, I., Peredo, A. M., and Nazareno, E. (2014). Worker cooperatives as an organizational alternative: Challenges, achievements and promise in business governance and ownership. Organization, 21(5): 591-603.

Chroneos Krasavac, B. and Petković, G. (2015). Cooperatives in Serbia - Evolution and current issues. Economics of Agriculture, 62(3): 723-736.

European agri-cooperatives (Cogeca) (2010). Agricultural co-operatives in Europe: Main issues and trends. Brussels: European agri-cooperatives. URL: http://www.agro-alimentarias.coop/ficheros/doc/03020.pdf (30.12.2019.)

Coleman, J. S. (1990). Foundations of social theory. Cambridge, MA: Belknap Press of Harvard University Press.

Corden, A. and Sainsbury, R. (2006). Using verbatim quotations in reporting qualitative social research: Researchers' views. York: University of York, Social Policy Research Unit. URL: https://www.york.ac.uk/inst/spru/pubs/pdf/verbquotresearch.pdf (14.03.2020.)

Cvetko, J. (1908). Što je Hrvatska seljačka zadruga i kako se osniva. Zagreb: Tisak Dioničke tiskare.

Davis, G. F. and Cobb, J. A. (2010). Resource dependence theory: Past and future. In: Bird Schoonhoven, C. and Dobbin, F. (eds.), Stanford's organization theory renaissance, 1970-2000 (pp. 21-42). Bingley: Emerald Group Publishing.

Defilippis, J. (2005). Development of the family holdings in Croatia and the co-operative movement. Sociologija sela, 43(1): 43-59. [Full text in Croatian only]

Draheim, G. (1955). Die Genossenschaft als Unternehmungstyp. Göttingen: Vandenhoeck \& Ruprecht.

Dutta, S, Lanvin, B. and Wunsch-Vincent, S. (eds.) (2019). Global Innovation Index 2019. Creating Healthy Lives-The Future of Medical Innovation. Ithaca, Fontai- 
nebleau, and Geneva: Cornell University, INSEAD, and the World Intellectual Property Organization. URL: https://www.wipo.int/edocs/pubdocs/en/wipo_pub_ gii_2019.pdf (06.12.2019.)

Đurkin Badurina, J. and Kljaić Šebrek, J. (2018). Cooperatives as organizational forms suitable for the sustainable development of tourism in rural areas. Notitia-journal for economic, business and social issues, 4(1): 29-38. [Full text in Croatian only]

Edquist, C. and Johnson, B. (1997). Institutions and organizations in systems of innovation. In: Edquist, C. (ed.), Systems of innovation: Technologies, institutions and organizations (pp. 41-63). Abingdon: Routledge.

Flanagin, A. J., Monge, P., and Fulk, J. (2001). The value of formative investment in organizational federations. Human Communication Research, 27(1): 69-93.

Friedman, M. and Friedman, R. D. (1980). Free to choose: A personal statement. San Diego: Harcourt.

Galor, Z. (2008). Demutualization of co-operatives: Reasons and perspectives. URL: http://co-oppundit.org/files/demutualizationcooperatives21508.pdf (04.01.2020.)

Global Innovation Index (GII) (2019). About the Global Innovation Index - Past reports. URL: https://www.globalinnovationindex.org/about-gii\#reports (06.12.2019.)

Golja, T. and Novkovic, S. (2014). Determinants of co-operative development in Croatia. In: Hammond Ketilson, L. and Robichaud Villettaz, M. P. (eds.), Co-operatives' power to innovate: Texts selected from the International Call for Papers (pp. 15-26). Lévis, Quebec: International Summit of Cooperatives.

Guest, G., MacQueen, K. M., and Namey, E. E. (2011). Applied thematic analysis. Thousand Oaks: SAGE.

Hansmann, H. (1996). The ownership of enterprise. Cambridge, MA: Harvard University Press.

Hardin, G. (1968). The tragedy of the commons. Science, 162(3859): 1243-1248.

Hechter, M. and Opp, K. D. (eds.) (2001). Social norms. New York: Russell Sage Foundation.

Hirschman, A. O. (1958). The strategy of economic development. New Haven: Yale University Press.

Hume, D. (edited by Selby-Bigge, L. A) (1896). A treatise of human nature. Oxford: Clarendon Press.

International Co-operative Alliance (ICA) (2019). Cooperative identity, values \& principles. URL: https://www.ica.coop/en/cooperatives/cooperative-identity (02.12.2019.)

Jussila, I. (2013). Inaugural editorial. Journal of Co-operative Organization and Management, 1(1): 1-5.

Lambru, M. and Petrescu, C. (2014). Surviving the crisis: Worker cooperatives in Romania. Organization, 21(5): 730-745.

Levi, Y. and Davis, P. (2008). Cooperatives as the "enfants terribles" of economics: Some implications for the social economy. The Journal of Socio-Economics, 37(6): 2178-2188. 
Mataga, Ž. (1995). Seljak i zadruga. Bjelovar: Prosvjeta.

Mataga, Ž. (2005). Agricultural co-operative movement in Croatia: Development and core issues. Sociologija sela, 43(1): 17-42. [Full text in Croatian only]

Mataga, Ž. (2009). Etičke vrijednosti i gospodarski značaj zadrugarstva. Zagreb: Vlastita naklada.

Mataga, Ž. (ed.) (2014). 150 godina poljoprivrednog zadrugarstva Hrvatske (1864.2014.). Zagreb: Hrvatski poljoprivredni zadružni savez.

Mathews, R. (2003). A future or no future: Credit unions in a globalising economy. Annual Conference of the New Zealand Association of Credit Unions, Hamilton, NZ, 12 September 2003. URL: http://racemathews.com/Assets/Mutualism\%20Coops\%20 CUs/2003\%2009\%20121\%20NZ\%20CUs\%20Speech.pdf (04.01.2020.)

Matijašević, A. (2005). Co-operative laws in Croatia: Development and problems of legislation concerning the agricultural co-operatives. Sociologija sela, 43(1): 153170. [Full text in Croatian only]

Mazzarol, T., Simmons, R., and Mamouni Limnios, E. (2011). A conceptual framework for research into co-operative enterprise. CEMI Discussion Paper Series, No. 1102. Perth: Centre for Entrepreneurial Management and Innovation. URL: https:// cemi.com.au/sites/all/publications/CEMI-DP1102-Mazzarol-Simmons-Limnios-2011.pdf (05.12.2019.)

Mazzarol, T., Mamouni Limnios, E., and Reboud, S. (2013). Co-operatives as a strategic network of small firms: Case studies from Australian and French co-operatives. Journal of Co-operative Organization and Management, 1(1): 27-40.

Ménard, C. (2004). The economics of hybrid organizations. Journal of Institutional and Theoretical Economics, 160(3): 345-376.

Ministry of Economy, Entrepreneurship and Crafts. (2019). Otvoreni javni poziv za Program „Razvoj zadružnog poduzetništva“ za 2019. godinu. URL: https://gospodarstvo.gov.hr/javni-pozivi/javni-pozivi-ministarstva/otvoreni-javni-poziv-za-program-razvoj-zadruznog-poduzetnistva-za-2019-godinu/11400 (04.01.2020.)

Nedanov, A. and Žutinić, Đ. (2018). A correspondence analysis of motivational factors for joining agricultural cooperatives in Croatia. New Medit, 17(3): 79-92.

North, D. C. (1990). Institutions, institutional change and economic performance. Cambridge: Cambridge University Press.

Novkovic, S. (2008). Defining the co-operative difference. The Journal of Socio-Economics, 37(6): 2168-2177.

Novkovic, S. and Golja, T. (2015). Cooperatives and civil society: Potential for local cooperative development in Croatia. Journal of Entrepreneurial and Organizational Diversity, 4(1): 153-169.

Olson, M. (1965). The logic of collective action. Cambridge, MA: Harvard University Press.

Ownership Associates (1998). Self-direction and employee ownership and motivation. OA working paper. Cambridge, MA: Ownership Associates. URL: http://www. ownershipassociates.com/selfdir.shtm (05.12.2019.) 
Ownership Associates (2001). Ownership and motivation. The Ownership Culture Report No. 4. Cambridge, MA: Ownership Associates. URL: https://www.ownershipassociates.com/pdf/ocr4.pdf (05.12.2019.)

Pavličević, D. (2010). Hrvatske kuíne / obiteljske zadruge. Volumes I and II. Zagreb: Golden Marketing - Tehnička knjiga.

Pejnović, D., Radeljak Kaufmann, P., and Lukić, A. (2016). Development and contemporary characteristics of agricultural cooperatives in the area of Croatia. Croatian Geographical Bulletin, 78(2): 5-48.

Pesämaa, O., Pieper, T., Vinhas da Silva, R., Black, W. C., and Hair Jr., J. F. (2013). Trust and reciprocity in building inter-personal and inter-organizational commitment in small business co-operatives. Journal of Co-operative Organization and Management, 1(2): 81-92.

Petak, A. (2005). Izazovi poljoprivrednog zadrugarstva - izazovi Hrvatske. Sociologija sela, 43(1): 5-16.

Pfeffer, J. and Salancik, G. R. (1978). The external control of organizations: A resource dependence perspective. New York: Harper \& Row.

Posavec, R. (2018). Pank poduzetnici. Čakovec: ACT Grupa.

Puljiz, V. (1992). Communal joint families, zadrougas, and "Zadruga" process of modernization in the modernization of the Croatian society. Sociologija sela, 30(115116): 147-154. [Full text in Croatian only]

Puusa, A., Mönkkönen, K., and Varis, A. (2013). Mission lost? Dilemmatic dual nature of co-operatives. Journal of Co-operative Organization and Management, 1(1): 6-14.

Rose, S., Spinks, N., and Canhoto, A. I. (2015). Management research: Applying the principles. Abingdon: Routledge

Rothschild-Whitt, J. (1979). The collectivist organization: An alternative to rational-bureaucratic models. American Sociological Review, 44(4): 509-527.

Rybnikova, I. and Hartz, R. (2014). Participation and economic growth in cooperatives: Empirical explorations of a (supposedly) well-known relationship. $4^{\text {th }}$ International Degrowth Conference. Leipzig, 2-6 September 2014. URL: https://www.degrowth. info/wp-content/uploads/2015/08/Degrowth2014_Rybnikova_Hartz_Participation-and-economic-growth-in-cooperatives-Empirical-explorations-of-a-supposedly-well-known-relationship.pdf (04.01.2020.)

Simmons, R., Ševarlić, M. M., and Nikolić, M. M. (2011). The role and potential of co-operatives in poverty reduction and local economic development in Serbia. Business. Education. Law - Bulletin of the Volgograd Business Institute, 14(1): 18-42.

Sivertsen, S. (1996). Governance issues seen from a management perspective. Review of International Co-operation, 89(4): 34-36.

Stanojević, I. (2015). Analiza zadružnog sustava u 2014. godini. Agronomia Croatica, 5(1): 51-57.

Stiglitz, D. J. (2009). Moving beyond market fundamentalism to a more balanced economy. Annals of Public and Cooperative Economics, 80(3): 345-360. 
Storey, J., Basterretxea, I., and Salaman, G. (2014). Managing and resisting 'degeneration' in employee-owned businesses: A comparative study of two large retailers in Spain and the United Kingdom. Organization, 21(5): 626-644.

Street, C. T. and Cameron, A. F. (2007). External relationships and the small business: A review of small business alliance and network research. Journal of Small Business Management, 45(2): 239-266.

Ševarlić, M. M., Nikolić, M. M., and Simmons, R. (2010). Agricultural cooperatives and their membership in cooperative unions in Serbia. APSTRACT: Applied Studies in Agribusiness and Commerce, 10(3-4): 25-32.

Šoljić, K., Pavličević, J., and Milas, Z. (2005). Cooperatives in Bosnia and Herzegovina: A step closer to Europe. Agronomski glasnik, 67(5): 393-425. [Full text in Croatian only]

Tratnik, M., Radinović, S., and Žutinić, Đ. (2007). Cooperatives in Croatia: Challenges to stability of farms. Agronomski glasnik, 69(1): 63-76. [Full text in Croatian only]

Turner, J. H. and Stets, J. E. (2005). The sociology of emotions. Cambridge: Cambridge University Press.

Vallati, J. A. (2012). Co-operative integration. Discussion paper. San José: Cooperativas de la Américas, and Buenos Aires: Cooperar. URL: https://www.aciamericas.coop/ IMG/pdf/3.1._jorge_vallati_en_con_firma_en.pdf (30.12.2019.)

Vidović, D. and Grubišić-Čabo, M. (2019). Uloga učeničkih zadruga u procesima izgradnje socijalne kohezije. $7^{\text {th }}$ National Congress of the Croatian Sociological Association "Social cohesion in society of polarisation, conflicts and inequalities".Zagreb, 11-12 April 2019.

Vidović, D. and Rakin, D. (2017). Social entrepreneurship and the revitalization of the cooperative sector: Emergence of social cooperatives in Croatia and Serbia. In: Baglioni, S., Roy, M., Mazzei, M., Srbijanko, J. K., and Bashevska, M. (eds.), Social enterprise developments in the Balkans (pp. 7-22). Skopje: Reactor - Research in Action.

Weber, M. (1968). Economy and society. Cambridge, MA: Harvard University Press.

Weismuller, J. P. (2012). Social movements and free riders: Examining resource mobilization theory through the Bolivian Water War. The Macalester Review, 2(2): article 4. URL: https://digitalcommons.macalester.edu/macreview/vol2/iss2/4 (11. 09. 2019.)

Zamagni, S. and Zamagni, V. (2010). Cooperative enterprise: Facing the challenge of globalization. Cheltenham: Edward Elgar Publishing. 


\title{
PRIČA O OŽIVLJAVANJU HRVATSKIH ZADRUGA: PREVLADAVANJE UNUTARNJIH PREPREKA \\ Jasmina Božić, Armano Srbljinović i Lucija Lučan
}

\begin{abstract}
Sažetak
Na temelju polustrukturiranih intervjua s voditeljima ili članovima 45 različitih zadruga iz svih hrvatskih regija, u radu identificiramo šest glavnih skupina unutarnjih zapreka boljem razvoju hrvatskih zadruga: 1) zapreke koje proizlaze iz „dvostruke“ prirode zadruga, 2) problem „slobodnih jahača“, 3) nedostatak inovacija u upravljanju, 4) nedovoljna pažnja usmjerena na vertikalnu suradnju medu zadrugama, 5) nepoduzimanje strateških koraka kako bi se osigurala podjela rada $i$ horizontalna suradnja $i$ 6) nerazvijenost mreža i protokola suradnje. Nakon rasprave o svakoj od navedenih prepreka s ciljem njihova prevladavanja, zaključujemo da se kombiniranim naporima odozgo prema dolje $i$ odozdo prema gore još mnogo toga može učiniti na oživljavanju stotina lokalnih zadruga koje trenutno ili jedva preživljavaju ili uopće nisu aktivne. I same bi zadruge trebale biti aktivnije u uspostavljanju platformi za suradnju odozdo prema gore. U sklopu mogućih poboljšanja djelovanja vlade, prije svega preporučujemo proširenje financiranja projekata tako da obuhvate i aktivnosti namijenjene jačanju vodoravne i okomite suradnje.
\end{abstract}

Ključne riječi: zadruge, Hrvatska, horizontalna suradnja, umrežavanje, kvalitativno istraživanje, malo poduzetništvo, vertikalna suradnja

\section{EINE GESCHICHTE ÜBER DIE WIEDERBELEBUNG KROATISCHER GENOSSENSCHAFTEN: ÜBERWINDUNG VON INNEREN HINDERNISSEN}

\author{
Jasmina Božić, Armano Srbljinović und Lucija Lučan
}

\begin{abstract}
Zusammenfassung
Aufgrund halbstrukturierter Interviews mit Leitern oder Mitgliedern von 45 unterschiedlichen Genossenschaften aus allen Regionen Kroatiens identifizieren wir in der vorliegenden Arbeit sechs Gruppen von inneren Haupthindernissen, die einer besseren Entwicklung von kroatischen Genossenschaften im Wege stehen: 1) Hindernisse, die sich aus der "dualen Natur" der Genossenschaften ergeben, 2) Das "Trittbrettfahrerproblem", 3) Mangel an Innovationen im Management, 4) Ungenügende Aufmerksamkeit auf die vertikale Zusammenarbeit unter Genossenschaften, 5) Es werden keine strategischen Schritte unternommen, um eine Arbeitsteilung und horizontale Zusammenarbeit zu sichern, 6) Unentwickelte Netzwerkprotokolle. Nach einer Diskussion über jedes von genannten Hindernissen, mit dem Ziel, sie zu überwinden, schließen wir, dass es sich mit Hilfe kombinierter Bemühungen von oben nach unten und von unten nach oben noch vieles machen lässt in puncto Wiederbelebung hunderter von lokalen Genossenschaften, die momentan kaum überleben oder gar nicht aktiv sind. Auch Genossenschaften selbst sollten sich aktiver an der Herstellung von Zusammenarbeitsplattformen von unten nach oben beteiligen. Im Zusammenhang mit möglichen Besserungen der Regierungsaktivitäten schlagen wir vor allem vor, Projekte auf einer breiteren Basis zu finanzieren, damit auch Aktivitäten umfasst werden, die zur Stärkung der horizontalen und vertikalen Zusammenarbeit beitragen.
\end{abstract}

Schlüsselwörter: Genossenschaften, Kroatien, horizontale Zusammenarbeit, Vernetzung, qualitative Forschung, Kleinunternehmertum, vertikale Zusammenarbeit 